s erre az áttekinthetôségre az állami pénzek hatékony felhasználása szempontjából feltétlenül szükség van. Az új kihívásokhoz történố alkalmazkodás szabályozási és intézményi feltételei még hiányosak, a valóságos eredmények kialakításával fontos szerepet játszanak az intézmények (normarendszer, érték- és szokásrend) köztük fontos feladatok hárulnak a pénzügyi intézményekre. A hazai gazdaságpolitika számára a hosszú távú fejlődéshez különösen figyelemre méltóak a szerzőnek az EU-val és a Gazdasági és Monetáris Unióval kapcsolatos fejtegetései.

R. I.

\section{KLEIN Balázs - KLEIN Sándor A SZERVEZET LELKE}

EDGE-SHL Kiadó. Budapest. 2006.

Állandó küzdelem a határidőkkel, hatalmas mennyiségú információ feldolgozása, nagy horderejú döntések szinte állandóan. Ilyen és hasonló tevékenységekból áll a szervezet menedzsereinek napi munkája. Tulajdonképpen ez a vállalatvezetés lényege. Nincs ebben új, a vezetés minden korszakban szükségszerüen ezt végezte. A vezetés folyamatos változásban van, új és újabb vezetốk cserélódnek, jelenlétük elsô jele rendszerint az átszervezés valamilyen ténye. Állandó jelenség, hogy a vállalatvezetóknek egyre újabb és újabb, vagy újnak álcázott vállalatvezetési módszereket ajánlanak a legkülönbözóbb helyekról, azt állítva, hogy ezekkel áttörésszerú eredményeket érhetnek el munkájukban. A javasoltak egy része kifejezetten divatjellegú, mások különbözô tapasztalatok nyomán látszanak ígéretesnek. A vállalatvezetési módszerek szószólói „szavatolják” a különböző felépítésú vállalatok átalakítását pl. tanuló szervezetté, az alkalmazottak motiválását a feladatkörök bővítésével (empowerment), teamszellemmel vagy diverzitás-menedzsmenttel (Diversity management), a vezetésnek ajánlják a leadership, coach eszközöket, a termékfejlesztési folyamat felgyorsítását párhuzamos múszaki tervezéssel, a szervezet egész értékalkotó láncát tökéletesítését stratégiai hálózatokkal és a tudásmenedzsment megerősítésével kívánják elfogadtatni. Nem egy esetben azt ígérik, hogy ezek közül a célok közül egyidőben több is megvalósítható. A képet még árnyaltabbá teszi, hogy az érvelớk szerint a fenti célokat úgy lehet elérni, hogy közben szem elôtt tartják a globalizáció feltételeit, kielégítik a nyílt környezetre, a fenntartható fejlődésre, az életen át történő tanulásra vonatkozó követelményeket, illetve folyamatosan érvényesítik a szervezet folyamatos tökéletesítését.
A vállalatvezetés szervezeti változtatásai többsége a divattól, a külsố hatások és kényszerek befolyásától, a vezetố ismereteitôl függ. A változtatások általában konkrét és sajátos szervezeti és kulturális feltételek között történnek, sikerük titka a problémaorientált alkalmazás. A hazai vállalatok a dokumentációkban, az információközpontok fejlesztésében és a szervezeti egységek együttmúködésében vélik a szervezeti hatékonyság biztositékát. Fontos szerepet tulajdonítanak a kompetenciáknak, a tudás munkafolyamatokba integrálásának, az alkalmazottak motiválásának. A tudáskövetelmények egy részét ugyanakkor nem igen tudják pontosítani, néhol hiányolják a hozzájutást a „fejekben lévő tőkéhez”.

A sikeres szervezeti múködés/múködtetés egyik feltétele azonban szervezetbe allokálódottak megfelelő megismerése és az ismeretek alapján a szervezeti emberi eróforrás „,kezelése”. Az ember mint a folyamatok alakítója, befolyásolója, kedvezményezettje vagy elviselóje kimaradhatatlan tényezô. Az erre a feladatra történő felkészítést, továbbképzést, a gyakorlatnak közvetlen támogató segítséget nyújtja az Edge Kiadó legújabb könyve, Klein Balázs és Klein Sándor legújabb munkája $A$ szervezet lelke.

A kiadó, az SHL Hungary Kft. kiadásában az illusztris szerzóktốl olyan múvet ad át az emberi eróforrással foglalkozóknak és más érdeklődóknek, amely megalapozott elmélettel, a gyakorlati megoldások sokszínúségével a sikeres alkalmazás lehetóségét teremti meg a felhasználók számára. A szervezet eredményessége, mint ismert, nagyrészt azokon a kölcsönhatásokon múlik, amellyel a szervezetben együttmúköooók befolyásolni képesek a múködéssel összefüggő belsố és külsô tényezốket. A szerzốk korábbi munkái tartalomban és formában jelzik a tudatos építkezést az eredményes vezetés és emberi eróforrás alakítás terén, hisz könyveik a Pszichológia a munka világában, sorozatban készülnek. A Munkapszichológia (1980 és újabb kiadásai), a Vezetés- és szervezetpszichológia (2002) majd ez az új mú közös elveket, nyelvet és gyakorlatot teremt az emberi eróforrásokkal foglalkozók számára. A szervezet lelke az elméletileg koherensen alapozott és a gyakorlatban alkalmazásorientált tudományos megközelítést tükrözik. Az ilyen minőség személyfüggő, amit a tudatos felkészülés, majd sokoldalú gyakorlat teremt meg, és amelyet a szerző szerényen saját pályaválasztását illusztrálva mutat be, ezzel is hitelesítve munkáját (p.661.).

Szerzőink $A z$ éló szervezet, Az ember megismerése, A viselkedés szabályozása, Figyeljünk egymásra, Humanisztikus vezetés, A szervezet stratégiája fófejezetekben, huszonegy részfeldolgozásban elemzően és integrált formában dolgozzák fel a bonyolult szervezeti/ környezeti és emberi viszonyrendszereket. A szervezet 
versenyfeltételének elengedhetetlen alapja a szervezeti tudás minél jobb fel- és kihasználása. Ez a tudás azonban a szervezet sajátos humántóke-specifikusságában tükröződik, amely ma egyre inkább a posztindusztriális foglalkoztatási modellbe ágyazódik. Innen válik Klein Balázs és Klein Sándor munkája érdekessé, mert tudományos színvonalon, harminc éve a munka világában eredményesen alkalmazott pszichológiai eszközrendszert sứít egybe azért, hogy a szervezetben múködó személyiség egyénileg és közösségében is sikeres lehessen. A rendszerelvúen összeállított kötet fô célja, hogy az emberi erôforrással kapcsolatos különféle tudományok módszertani kérdéseiból és tipi kus megoldásra váró problémáiról általános következtetéseket vonjon le. Ezekból pedig - a gazdag esettanulmányokkal bizonyitva - a sikeres eljárásokat tudatosítsa. A hazai emberi eróforrás-szakirodalomban A szervezet lelke kötet pszichológiai akciókutatásokkal kimunkált ismeretrendszere és szemléletmódja azt vallja, hogy a tudomány eredményeinek, illetve a tudományok múvelése során született eredményeknek a szervezet gyakorlatába történố beültetésével az emberi erôforrás minőségi múködése valósulhat meg. A változó piacgazdaság eseményei között legalább az emberról tudjunk még több valóságost - ezt szolgálja A szervezet lelke, ezzel segítve azt, hogy a szervezetek emberitóke állományuk növekvő részét is egyre inkább a portfólióbefektetések kezeléséhez hasonló rugalmassággal irányítsák.

Dr. Krisztián Béla

\section{PATAKI Béla A TECHNOLÓGIA MENEDZSELÉSE}

Gyorsuló Tudomány, Typotex, Budapest, 20o5. 207 p.

A tudomány gyorsuló fejlódése a tudományos könyvkiadást is új kihívások elé állítja. Ennek jegyében született a „Gyorsuló tudomány sorozat”, melynek indításával a kiadó bepillantást kíván nyújtani az olvasónak a tudomány egy-egy szeletébe. A sorozat elsố kötetét tarthatja kezében az érdeklődő, Pataki Béla, a Budapesti Múszaki és Gazdaságtudományi Egyetem docensének könyvét. A tudásalapú társadalomban és gazdaságban a technológiamenedzsmentnek kulcsszerepe van a vállalatok sikeres múködésében. A szerző öt fejezetben fejti ki mondanivalóját. A elsóben a technológiamenedzsment alapfogalmát, a technológiák típusait, a menedzsment fogalmát, a technológiamenedzsment fogalmát és szerepét, továbbá a technológiamenedzs- ment kialakulását mutatja be. Pataki Béla a következő meghatározását adja a hazai gyakorlatban némelykor zavarosan értelmezett menedzsmentfogalomnak: emberi, fizikai, pénzügyi és információs erőforrások tervezése, szervezése, irányítása és vezetése a szervezet céljainak eredményes és hatékony kitűzése és elérése érdekében. Fontos megállapítás, hogy nemzetközi példák tanúsága szerint nem finanszírozási vagy marketing, hanem technológiai és a mögöttük meghúzódó technológiamenedzselési fogyatékosságok vezetnek a legtöbb esetben üzemek megszúnéséhez. E felismerésból született a technológiamenedzsment koncepiója.

A könyv második fejezete a technológiai életciklusokat, egyebek közt a technológiai életciklus-görbéket, a technológiák differenciálódását, valamint a menedzseri tévhiteket vázolja az új techológiákról. Több évtizedes megfigyelések alapján kilenc tévhitet sorol fel a szerző, melyek a menedzserek fejében élnek, ilyen például: a technológiai előrelépések vagy felfedezések végül rendszerint sikeresen terjednek el. A valóságban: a legtöbb nem válik sikeressé. A következô, harmadik fejezetben az információtechnológia menedzseléséról esik szó: A vállalat IT vagyona, Mennyire általános ez a gondolkodásmód? A felsô szintû́ menedzsmentre tartozó IT döntések, Lehet-e stratégiai versenyelóny forrása az IT? tagolásban. A vállalati versenyképesség alapja: IT - humánerőforrás, technológiai bázis, erôs partneri kapcsolat az IT és a vállalat menedzsmentje között. Ebben a fejezetben foglalkozik Pataki Béla azzal a vitával, amelyet Nicolas G. Carr Harvard Business Review-ban megjelent cikke váltott ki az IT-nak a stratégiai versenyelóny megszerzésében játszott szerepéról.

A negyedik fejezet a technológia stratégiai jelentôségét, tartalmát, az esetleges típushibákat, portfólióelemzést és a technológiatérképet ismerteti meg az olvasóval. A technológiatérkép kulcsfontosságú technológiamenedzsment eszköz, amely képessé teszi a vállalatot, hogy összekapcsolja technológiai képességeit termékeivel és üzleti terveivel, úgy hogy a stratégia és a technológia fejlesztése együtt haladjon. A könyv befejező fejezetében a magkompetencia-menedzsment témakörében elméletról, vitákról, teendőkról olvashatunk. A könyvet hasznos függelék és irodalomjegyzék zárja, amely a téma szakirodalmáról ad részletesebb tájékoztatást.

Pataki Béla könyve jó bevezetóje lehet egy olyan sorozatnak, amely a tudományos fejlódés egy-egy jelenségét közelebb kívánja hozni mindennapjainkhoz, amely a múszaki és gazdasági folyamatokat egységben, egymásra való kölcsönhatásában mutatja be. Várjuk a folytatást.

Becsky Róbert 